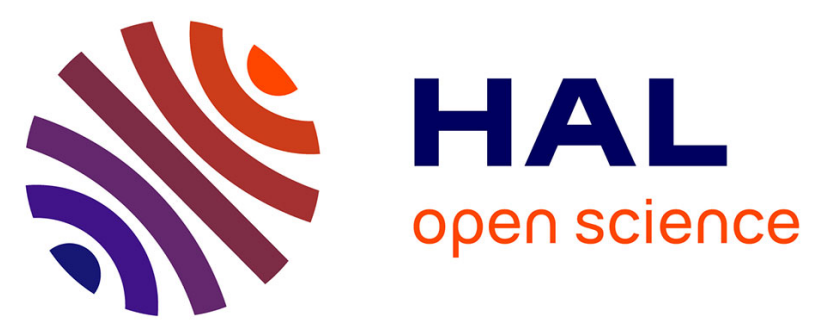

\title{
Seasonal variations in lipid composition of the hydrothermal vent mussel Bathymodiolus azoricus from the Menez Gwen vent field
}

Ana Colaço, Catarina Prieto, Ana Martins, Miguel Figueiredo, Virginie Lafon, Margarida Monteiro, Narcisa M. Bandarra

\section{To cite this version:}

Ana Colaço, Catarina Prieto, Ana Martins, Miguel Figueiredo, Virginie Lafon, et al.. Seasonal variations in lipid composition of the hydrothermal vent mussel Bathymodiolus azoricus from the Menez Gwen vent field. Marine Environmental Research, 2009, 67 (3), pp.146. 10.1016/j.marenvres.2008.12.004 . hal-00501989

\section{HAL Id: hal-00501989 \\ https://hal.science/hal-00501989}

Submitted on 13 Jul 2010

HAL is a multi-disciplinary open access archive for the deposit and dissemination of scientific research documents, whether they are published or not. The documents may come from teaching and research institutions in France or abroad, or from public or private research centers.
L'archive ouverte pluridisciplinaire HAL, est destinée au dépôt et à la diffusion de documents scientifiques de niveau recherche, publiés ou non, émanant des établissements d'enseignement et de recherche français ou étrangers, des laboratoires publics ou privés. 


\section{Accepted Manuscript}

Seasonal variations in lipid composition of the hydrothermal vent mussel Bathymodiolus azoricus from the Menez Gwen vent field

Ana Colaço, Catarina Prieto, Ana Martins, Miguel Figueiredo, Virginie Lafon, Margarida Monteiro, Narcisa M. Bandarra

PII:

S0141-1136(08)00261-4

DOI: 10.1016/j.marenvres.2008.12.004

Reference:

MERE 3310

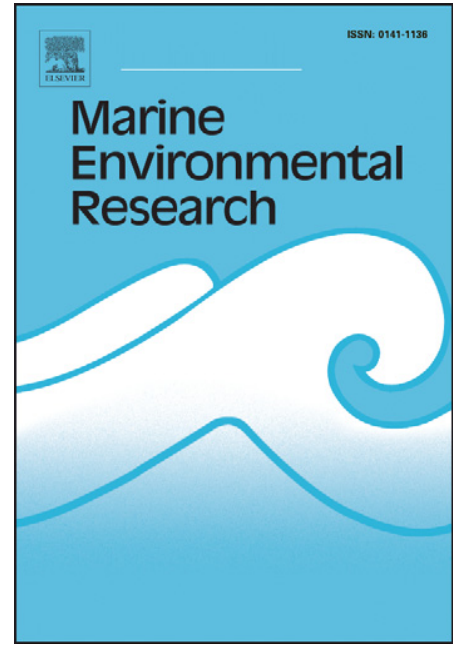

To appear in:

Marine Environmental Research

Received Date:

16 April 2008

Revised Date:

11 December 2008

Accepted Date:

15 December 2008

Please cite this article as: Colaço, A., Prieto, C., Martins, A., Figueiredo, M., Lafon, V., Monteiro, M., Bandarra, N.M., Seasonal variations in lipid composition of the hydrothermal vent mussel Bathymodiolus azoricus from the Menez Gwen vent field, Marine Environmental Research (2008), doi: 10.1016/j.marenvres.2008.12.004

This is a PDF file of an unedited manuscript that has been accepted for publication. As a service to our customers we are providing this early version of the manuscript. The manuscript will undergo copyediting, typesetting, and review of the resulting proof before it is published in its final form. Please note that during the production process errors may be discovered which could affect the content, and all legal disclaimers that apply to the journal pertain. 
1 Title:

2 Seasonal variations in lipid composition of the hydrothermal vent mussel Bathymodiolus azoricus

3 from the Menez Gwen vent field

4

5

6 Running Head:

$7 \quad$ Seasonal variation lipids vent mussel

8

9

10 Authors and addresses:

11

12 Ana Colaço ${ }^{1 *}$; Catarina Prieto ${ }^{1}$; Ana Martins ${ }^{1}$; Miguel Figueiredo ${ }^{1}$; Virginie Lafon ${ }^{1}$; Margarida

13 Monteiro $^{2}$; Narcisa M. Bandarra ${ }^{2}$

14

15 1-IMAR - Centro da Universidade dos Açores- Department of Oceanography and Fisheries, 16 Cais de Sta. Cruz 9001-382 Horta, Azores, Portugal.

17 2-INRB/IPIMAR Nutrition Laboratory, Av. Brasília, 1449-006 Lisbon, PORTUGAL

18 * Author to whom correspondence should be addressed acolaco@uac.pt

19

20

21 


\section{ABSTRACT:}

23

24 Specimens of the hydrothermal mussel Bathymodiolus azoricus collected in Menez Gwen

25 hydrothermal vent field (NE Atlantic) during 2002-2003 were examined for feeding patterns

26 variations through three seasons. The fatty acid profile and lipid classes of the mussels were

27 studied, together with the MODIS/AQUA derived near-surface chlorophyll $a$ to test the hypothesis

28 that surface productivity might be related to the feeding patterns of this species. The lipid levels

29 showed pronounced seasonal fluctuations with the highest values occurring in January and August.

30 Seasonal variations in lipid classes and fatty acid composition of neutral and polar lipids in the

31 mussels are presented. Differences in the fatty acid profile of lipid classes in different seasons

32 suggest that the higher energy requirements in summer and winter were supplied by bacterial

33 biomarkers $\omega 7$ MUFA (monounsaturated fatty acids), whereas $\omega 6$ PUFA (polyunsaturated fatty

34 acids) and NMI (nonmethylene-interrupted) fatty acids predominated during the spring. The

35 MODIS/AQUA data show marked seasonal variability and an anomalous peak during January of 362003 , although this cannot be directly linked to lipid composition variation.

37

38

39

40

41

42

43

44

KEY WORDS: Menez Gwen, Bathymodiolus azoricus; seasonality; lipids; fatty acids; biomarkers, hydrothermal activity 
45

\section{INTRODUCTION}

46

All production in the deep-sea, with the exceptions of the hydrothermal vent environments is fuelled, either directly or indirectly, by the import of organic matter to the bottom (Gage and Tyler, 1991), either as particulate matter (the detrital food chain) or by vertical migration (the grazing food chain) (Raymont, 1983). Although primary production by chemosynthetic bacteria at hydrothermal vents constitutes a rich source of organic carbon in the deep-sea, some vent species do not meet all their nutritional requirements solely from this carbon source (Allen et al., 2001). Seasonal variations in surface primary production may be reflected in vent species, particularly in shallow vent fields such as the Menez Gwen (Mid-Atlantic Ridge, $840 \mathrm{~m}$ ), since surface particles are estimated to sink at a rate of about 100 meters per day (Gage and Tyler, 2001). The mussel Bathymodiolus azoricus dominates communities associated with deep-sea hydrothermal vents in the Azores Triple Junction (ATJ) region, at depths ranging from 840 meters at Menez Gwen vent field to 2300 meters at Rainbow vent field (Colaço et al., 1998; Desbruyères et al., 2001). This species is known to live in dual symbiosis (with thio- or methanotrophic bacteria on its gills) (Fiala et al. 2002; Duperron et al., 2006), and use the symbionts for nutritional purposes (Pond et al., 1998; Colaço et al., 2002). The genus Bathymodiolus is considered a "generalist" in the hydrothermal vent habitat, as it is able to take advantage of both suspension-feeding and the production of its endosymbionts (Le Pennec et al., 1984). Some pelagic material has been found in the gut of specimens (Colaço, 2001), which shows that this species is able to use the detritus food chain.

Although primary production by chemosynthetic bacteria at hydrothermal vents constitutes a rich source of organic carbon in the deep-sea, some vent species do not meet all their nutritional requirements from this carbon source alone (Allen et al., 2001). The hypothesis that the particle flux from the upper ocean layers can contribute to the carbon uptake by the mussel can be tested 
by checking for biomarkers of surface primary producers in the mussel body, such as specific fatty acids. In the Menez Gwen region, marked seasonal variation in near-surface Chl $a$ and sea surface temperature is evident from the results of this study. These Chl $a$ cycles might be reflected in the lipid composition of the vent mussel, especially in those from the shallowest vent field Menez Gwen, since these are the biomarkers that persist in the pelagic food chain (Daalsgard et al, 2003).

Animal diets are usually verified by gut contents and faeces analysis or by behavioural studies. However, these data only provide information on food consumption during a brief window of time, and there may be a discrepancy between the diet ingested and the absorption / incorporation of the different food items into the mussel tissues. Lipids are major sources of metabolic energy (neutral lipids) and essential materials for the formation of cell and tissue membranes (polar lipids). The fatty acid composition of marine organisms reflects to some extent the fatty acid pattern of their food sources (Sargent et al., 1987; Howell et al., 2003) since the FA are destined either for oxidation to provide energy (ATP) or for incorporation into phospholipids (Sargent, 1995; Sargent et al, 1995). Diatoms, flagellates, macroalgae and bacteria may be distinguished by their fatty acid composition. Fatty acids as dietary traces in the marine environment help to explore food origins of various marine invertebrates (Howell et al., 2003; Suhr et al., 2003; Laureillard et al., 2004) and the relationships in food webs within communities and marine ecosystems (Kharlamenko et al., 1995; Phleger et al., 1999). For example, the fatty acids $18: 4 \omega 3 ; 20: 3 \omega 3 ; 22: 5 \omega 3 ; 22: 6 \omega 3$ and phytanic acid are photosynthetic biomarkers (Bergé and Barnathan, 2005). Therefore, comparison of fatty acid profiles among mussels collected at different seasons can be used to gain further information about the feeding habits of this bivalve. In order to acquire a better understanding of the lipid composition of stored and structural fat of this species, this work was carried out during three different seasons to i) investigate seasonal variations in lipid content and compositions, and fatty acid compositions of the mussel B. Azoricus and ii) acquire a better understanding of the role of photosynthesis-derived carbon on mussel nutrition. 


\subsection{Sampling}

97 During the SEAHMA (Seafloor and Sub-Seafloor Hydrothermal Modelling in the Azores Sea)

98 cruise in August 2002, specimens of deep-sea hydrothermal-vent mussels, B. azoricus Von Cosel,

99 Comtet and Krylova, were collected at the Menez Gwen vent field, located at approximately $37.51^{\circ} \mathrm{N}$ and $32.31^{\circ} \mathrm{W}$ (at $840 \mathrm{~m}$ depth), using the French ROV Victor 6000 and the French R/V

"L'Atalante". At that time, retrievable cages (Dixon et al., 2001) were moored and filled with mussels ( 200 mussels per cage) using the ROV. These were then placed at diffuse venting areas (the natural mussel habitat). These cages were then recovered in January and April 2003 with the Portuguese R/V Arquipelago. Pruski and Dixon, (2003, 2007) showed that the retrievable cages provided a much less stressful collection method than the ROV. The content of the mussel cages was shared with other researchers for various studies. At the time of recovery, three mussel samples from each recovery batch were dissected and soft tissue frozen at $-80^{\circ} \mathrm{C}$ for subsequent laboratory analyses.

\subsection{Lipid extraction}

Total lipids were extracted according to the Bligh and Dyer method (1959) as modified by White

111 et al., (1979). The lipids were then separated into different fractions using solid phase extraction 112 chromatography in silica gel columns (Isolute ${ }^{\circledR}$ SPE Columns). Non-polar lipid components were 113 separated with $7.5 \mathrm{ml}$ of diethyl ether-hexane (1:1). The medium polar lipid fraction (mainly 114 glycolipids) was extracted with $7.5 \mathrm{ml}$ of acetone and the high polar lipid fraction (mainly 115 phospholipids) was recovered with $15 \mathrm{ml}$ of methanol. The absolute value of each lipid fraction 116 was obtained by weight after solvent evaporation. The relative percentage of lipid classes (polar 
and non polar) and the different polar lipid components were determined by HPLC equipped with an evaporative light scattering detector (ELSD) using the methodology previously used by Bandarra et al. (2001).

\subsection{Fatty acid analyses}

Fatty acid methyl esters (FAMEs) were prepared using base-catalysed transesterification with sodium methoxide $0.5 \mathrm{M}$ solution in anhydrous methanol $\left(2 \mathrm{~h}\right.$ at $\left.30{ }^{\circ} \mathrm{C}\right)$, as proposed by Park et al (2001) and Kramer et al (2002).

FAME analyses were performed in a Varian CP 3800 (Walnut Creek, CA, USA) gas chromatograph equipped with an auto sampler and fitted with a flame ionisation detector at an injection temperature of $250^{\circ} \mathrm{C}$. The separation was achieved using a capillary column HPINNOWAX (30 m length, $0.25 \mathrm{~mm}$ internal diameter and $0.25 \mu \mathrm{m}$ film thickness) from Agilent (Albertville, MN, USA). Temperature was initially kept at $180^{\circ} \mathrm{C}$ for 5 minutes. Then, it was raised at a rate of $4^{\circ} \mathrm{C} /$ minute up to $220^{\circ} \mathrm{C}$, and maintained at $220^{\circ} \mathrm{C}$ for 25 minutes with the injector set at $250^{\circ} \mathrm{C}$. The split ratio was $100: 1$ and the measurement was taken using $\mathrm{C} 21: 0$ as an internal standard. The FAME identification was made by comparison to standards and whenever there was any question about the results, an FA structural verification (see below) was performed. The fatty acid profile was obtained by calculating the relative area percent of the chromatographic peaks using C21:0 fatty acid as internal standard. All analytical determinations were made in triplicate.

The concentration of each FAME was reported as $\mathrm{mg} \mathrm{g}^{-1}$ dry weight of tissue.

\subsection{FA structural verification}

Due to the specific nature of the samples, which can have unusual fatty acids, a derivatization method was used to further verify the mono and polyunsaturated double bond position of the identified FAME. The 4,4-dimethyloxazoline (DMOX) (Fay and Richli. 1991) derivatives were 
140

prepared by re-dissolving in $500 \mu \mathrm{l}$ of 2-amino-2-methylpropanol (FLUKA) heating overnight at $180^{\circ} \mathrm{C}$. After cooling, the reaction mixture was dissolved in $5 \mathrm{ml}$ of dichloromethane and washed twice with distilled water. The dichloromethane solution was dried with $\mathrm{Na}_{2} \mathrm{SO}_{4}$ and evaporated under a stream of nitrogen flow at room temperature. The residue was dissolved in n-hexane for analysis by gas chromatography-mass spectrometry (GC-MS).

The compounds were analysed with a gas chromatograph (Finnigan Trace gas chromatograph ultra) coupled with a mass spectrometer (Finningan Polaris Q mass spectrometer system - Thermo Electron Corporation, MA, USA)). A splitless injection was performed with $1 \mu$ l of sample. The carrier gas was helium at 10 Psi. A $25 \mathrm{~m}$ x $0.25-\mathrm{mm}$ id x $0.25 \mu \mathrm{m}$ HP-5 ${ }^{\circledR}$ (Hewlett-Packard) column was used. The GC-MS conditions for DMOX derivatives elution were as follows: started with 2 minutes at $90^{\circ} \mathrm{C}$, followed by a $5^{\circ} \mathrm{C} \mathrm{min}^{-1}$ ramp up to $280^{\circ} \mathrm{C}$ over 20 minutes.

\subsection{Chlorophyll $a$ concentration and surface temperature measurements derived from} satellite images

Monthly MODIS/AQUA-derived near-surface chlorophyll $a(\mathrm{Chl}$ a) and sea surface temperature (SST) images were obtained for a region above the mid-Atlantic Ridge at approximately $37^{\circ} \mathrm{N}$, $31^{\circ} \mathrm{W}$ (Menez Gwen). MODIS spatial resolution is $1.1 \mathrm{~km}$ resolution. Chlorophyll $a$ and SST images were obtained using the Ocean Chlorophyll 3 bands OC3M (O’Reilly et al. 2000) and long-wave SST (LW-SST) (Franz, 2006) algorithms, respectively. Regular daily MODIS images were obtained from the Ocean Colour Level 1/2 browser (OceanColor Web 2006). These images are mapped (Level2-map) with SeaDAS, and a master file was created specifically for the Menez Gwen region. The download and mapping process is automated within the HTRP (High Resolution Picture Transmission) station in the Azores HAZO- system developed by Figueiredo et al. (2004).

MODIS data was used to study the monthly and inter-annual surface pigment and temperature variability at Menez Gwen between 2002 and 2008. Only Chl $a$ values below 0.05 and above $7 \mathrm{mg}$ 
$164 \mathrm{~m}^{-3}$ were excluded from further analysis due to pixel contamination from clouds, aerosols and/or 165 suspended sediment. Only SST values above $10^{\circ} \mathrm{C}$ and below $30^{\circ} \mathrm{C}$ were used to avoid "false" low water temperature values due to pixel cloud contamination.

167

\subsection{Statistical analysis}

The Kruskall Wallis test (Zar, 1999) was applied to test for seasonal differences in polar and neutral lipid composition of $B$. azoricus. A significance level was established at 0.05 .

171

172

173

174

175

176

177

178

179

180

181

182

183

184

185

A principal component analysis (PCA) (Legendre and Legendre, 1998) was performed using the different FA profiles as descriptors for different individuals in order to determine whether the polar lipids and neutral lipids differ in specific seasons and between seasons.

\section{RESULTS}

\subsection{Lipid classes}

The total lipid content of B. azoricus varied significantly (Kruskal-Wallis test: $H(3,3,3)=7.20 \mathrm{p}$ $=0.027$ ) with the season (Table 1). The lowest levels were found in spring, while in summer the mussels showed approximately a three-fold increase. The relative proportion of polar and nonpolar lipid content in the total tissue also showed a tendency to vary throughout the year.

The non polar lipid content as a percentage of total lipids also showed seasonal variation (see Table 1). The highest levels were found in winter (91\%), while spring and summer showed the same percentages $(76 \%)$.

The polar lipid fraction was lowest during winter $(8.5 \%)$, with the spring and summer showing 186 similar percentages (\%). 
Phosphatidylethanolamine (PE) and cardiolipine (CL) were most abundant during summer, while the phosphatidylcholine (PC) reached its peak level in spring.

\subsection{Fatty acids}

The fatty acid profile of polar lipids (PL) and non-polar lipids (NPL) was analyzed for the winter, spring and summer months. A wide variety of fatty acids were detected (Table 2).

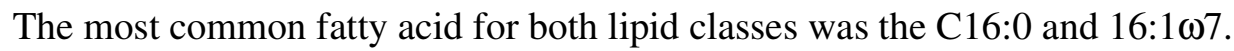

In the PL fraction, 20:3 16 showed the highest percentage, reaching over 50\% during winter. The

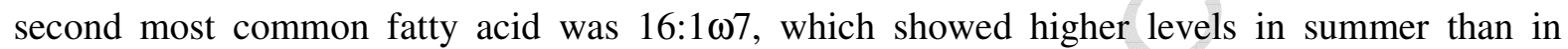

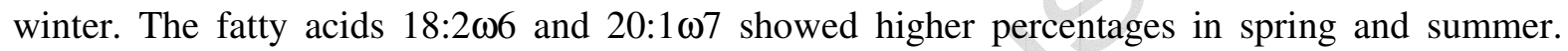
Nevertheless, in these seasons 22:613 appeared in significant amounts. Although the C18:1 group represented approximately $6 \%$ of the polar lipids in all seasons, the highest contributor to the

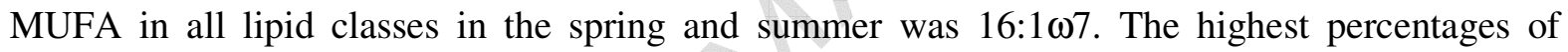
PUFA were present during winter and the lowest in the spring and summer. Branched fatty acids showed no evidence of seasonal variation.

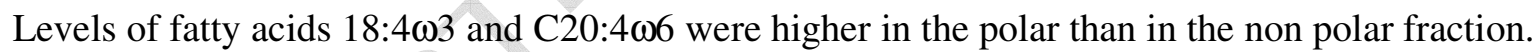

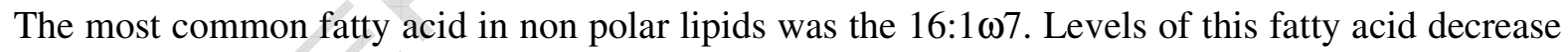
in spring and increase in summer. Fatty acids $20: 1 \omega 7$ and $22: 2 \omega(9,15)$ were also important components $(>5 \%)$ in this lipid fraction in all seasons. However, it was observed that the registered

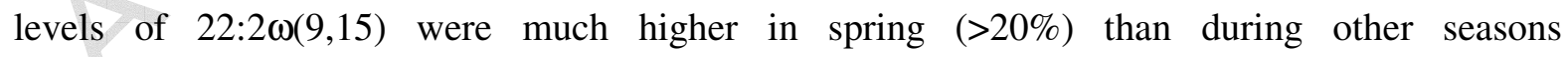
(approximately 5\%).

In non-polar lipids MUFA showed a significant decrease during spring. This decrease was mainly due to the $\omega 7$ fatty acids. PUFA showed highest levels in spring. Despite the low quantities, branched fatty acids were more important in winter compared with other seasons. The NMI fatty 
210 acids were more abundant in NPLs and reached their peak levels in spring. The non methylene

211 interrupted dienoic (NMID) fatty acids C20:2 was very important to the non-polar fraction in all 212 seasons, with C22:2 being very important in the spring.

213 The polar lipid fraction also showed a high proportion of $\mathrm{C} 20: 3 \omega 6$, while in the non-polar fraction,

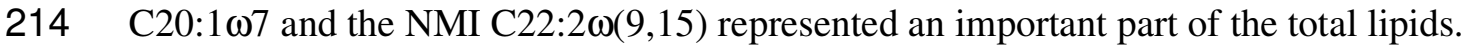

216 Photosynthetic biomarkers did not appear in significant percentages in the samples analysed. There 217 were no significant differences between seasons and the highest percentage found was in the PL 218 fraction. Despite the lack of seasonal variation in the $\omega 3$ fatty acids family of both lipid fractions, 219 the percentage of $\omega 3$ and $\omega 6$ PUFA in the PLs was significantly higher $(\mathrm{p}<0.05)$ than in the NPL, with the exception of $\omega 6$ fatty acids, whose levels increased during the spring.

The PCA showed that there were no major differences between the different lipid classes and seasons. The first component explains $71.73 \%$ of the variance and all the individuals are grouped in one end of the firts component. The second component explains only $16.85 \%$ of the variance

224 The individuals from the winter sampling showed more differences, mainly due to fatty acid 225 C20:3w6, which contributed by almost 67\% to the second factor (Fig.2).

\section{$226 \quad 3.4$ Satellite Data}

227 MODIS near-surface Chl $a\left(\mathrm{mg} \mathrm{m}^{-3}\right)$ and surface temperature (SST in $\left.{ }^{\circ} \mathrm{C}\right)$ monthly medians were 228 calculated for the Menez Gwen region from June 2002 through to March 2008 (Fig. 1). During this 229 period of time, strong spring Chl $a$ bloom signals were evident. Spring blooms began at different 230 times in different years. During the first two years (2002 and 2003), late spring blooms 231 (April/May) were observed, while in the later years the blooms commenced earlier (March/April). 232 The highest Chl $a$ monthly averages $\left(0.30-0.35 \mathrm{mg} \mathrm{m}^{-3}\right)$ were found during the years 2003, 2005, 233 and 2008 and the lower averages $\left(0.05-0.09 \mathrm{mg} \mathrm{m}^{-3}\right)$ were found in 2002, 2004, 2006 and 2007. 
234 In addition, Chl- $a$ autumn blooms of a smaller amplitude were more or less visible in 2002-2003

235 while late "autumn" blooms (Dec/Jan) were observed in subsequent years (2004 to 2007). For all

236 years, the lowest monthly Chl $a$ averages were observed during summertime.

\section{DISCUSSION}

239

The total lipid content of B. azoricus varied markedly $(\mathrm{p}<0.05)$ depending on the season. The lowest values were found in spring, while in summer the mussels showed an approximately threefold increase. Since phytoplankton blooms occur in the spring at this latitude in surface waters (see Fig. 1), this result was somewhat unexpected. Nevertheless, if they feed primarily on material resulting from zoo- and phyto-degradation, there would be a time lag, which would tend to explain the higher levels in summer.

Winter was the period with the lowest level of PLs in membranes, probably due to the utilization of some structural lipids to maintain the body during periods of food scarcity and reproduction.

The high NPL content in the winter suggests that a significant portion of the total lipids exist as energy reserves in this season. The relative amounts of these compounds, however, varied along the year. According to Colaço et al (2006) and Dixon et al (2006), this species is sexually mature in winter. The gonadal cell proliferation must at some stage involve intense biochemical synthesis of protein and lipid reserves for egg production, thus explaining the high level of NPLs (storage lipids) during winter (Holland, 1978). Since sexual reproduction is an energy-intense process, the dramatic decrease in NPLs after winter suggests that the this lipid class may be used as energy reserves for reproduction purposes, and the subsequent decrease observed is probably correlated with spawning. Several authors (Gardner \& Riley 1972; Swift, 1977; Beninger \& Stephan, 1985, Pazos et al. 1997 and Soudant et al. 1999) observed changes in the neutral lipids in other mytilids 
due to reproduction, whereas the polar lipids were influenced to a lesser extent and remained

258 practically constant over the year.

259 The higher PE and CL values in summer are in accordance with the highest levels of bacterial fatty 260 acid biomarkers present in this season, since PE is frequently the main lipid component of 261 microbial membranes, and CL is found only in the membranes of bacteria and mitochondria (Kraffe et al, 2005). The PC is usually the most abundant phospholipid in animal and plant tissue membranes, often amounting to almost $50 \%$ of the total (Christie, 1989). On the other hand, it is less often found in bacterial membranes, probably in only $10 \%$ of species (Christie W.L. 2007). Its higher level in spring may be related to the abundant availability of particles due to the spring bloom. The low level of PC in winter, the period with the lowest level of structural lipids, confirms the probable use of this phospholipid in mussel lipid body metabolism maintenance.

\subsection{Fatty acid composition:}

The fatty acid composition of an animal can be used as an indicator of its trophic ecology (Sargent et al. 1987, Colaço, et al. 2007). Deep-sea hydrothermal vent animals use the organic metabolites produced by bacteria as a food source (Pond et al. 2000; Colaço et al. 2002), and until recently it was generally accepted that the contribution of photosynthetic-derived material was negligible.

In the present work, the presence of the $\omega 7$ fatty acid family and the NMID, whether in the NPL or PL fraction, indicate a clear dependence on bacterial-derived carbon in all seasons. The presence

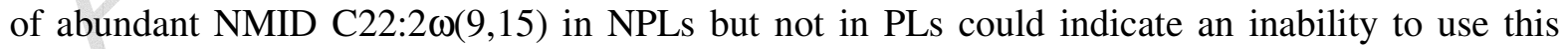

277 fatty acid for physiological or structural purposes and thus might explain its accumulation in NPLs 278 for energy needs as observed by Sato and Ando (2002) in brittle stars.

The presence of phytanic acid, even in small proportions, reflects utilization by the vent mussels of 
281 family of fatty acids did not show seasonal variations like those of the fatty acids from the $\omega 6$ 282 family. The former appeared in higher percentages in the NPL fraction in spring, while in the PL

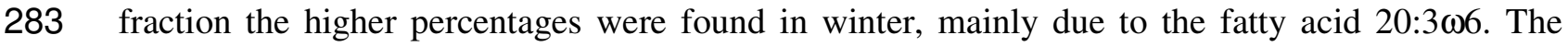
284 presence of greater quantities of the $\omega 3$ family in the PL fraction than in the NPL fraction seems to 285 indicate that the former are principally incorporated and used for structural functions, rather than 286 for energy purposes, which is congruent with their role as essential fatty acids. In marine animals 287 the fatty acids comprising the lipid reserves are mainly saturated or monounsaturated (Pond et al. 288 2000), which is in line with the results of this work.

289 In PLs, the high level of PUFA 20:4 290 seasonal biochemical synthesis of reproduction lipid structures, which takes place during this 291 season. This fatty acid is a precursor of prostaglandins, and prostaglandins play a key role in the 292 reproductive processes of molluscs (Morse 1984).

293 In this study, branched fatty acids did not change during the year, but the results suggest that they 294 may contribute towards an implementation of reserve lipids during winter, as reflected in the 295 greater amounts of non-polar lipids found during this season.

296 The composition of the fatty acid profile of $B$. azoricus confirms the existence of a food chain 297 based on bacterial chemosynthetic rather than phytoplanktonic primary production (Fisher 1990).

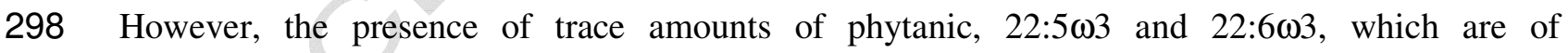
299 phytoplanktonic origin, is probably related to the ability of the vent mussel to filter-feed on 300 external particulate material.

301 The hydrothermal mussels have ingested this available material. The slow uptake of fatty acids in 302 the PL class explains the high levels of total lipids in the summer. This fact could explain the 303 higher amounts of PUFAs $\omega 3$ and other phytoplankton biomarkers such as $\omega 6$ in NPLs during 304 spring. 

The presence of phytanic acid reflects the utilization of surface organic material by the vent mussels. However, phytanic acid and other photosynthetic-derived fatty acids are never present in large quantities in this species, even when phytoplankton blooms are evident in surface waters. This species relies mainly on chemosynthetic-derived material, and the variations observed are probably due more to physiological stages (e.g. reproduction) than to seasonal variations of sea

311 surface water productivity.

312 Further studies will be fundamental to improving our understanding of how this surface-bottom 313 relationship is established / maintained and to quantify its importance.

\section{ACKNOWLEDGEMENTS:}

316 The authors wish to acknowledge the crews of the RV 'L'Atalante and the RV 'Arquipélago', as

317 well as the 'VICTOR 6000' teams for their field support. We would like to thank Prof. F. Barriga, 318 who served as the chief scientist for the mission SEAHMA I. MODIS satellite data was obtained 319 from NASA/GSFC and processed at the Department of Oceanography and Fisheries of the 320 University of the Azores (DOP/UAç). IMARDOP/UAz is Research and Development Unit \#531 321 and Associated Laboratory \#9 funded by the Portuguese Foundation for Science and Technology 322 (FCT) through pluri-annual and programmatic funding schemes (FEDER, POCI2001, FSE) and by 323 the Azores Directorat for Science and Technology (DRCT).This research is a contribution of 324 project PDCTM/P/MAR/15281/1999/ SEAHMA - Seafloor and sub-seafloor hydrothermal 325 modeling in the Azores sea (POCI-POSI-FEDER). OPALINA (PDCTE/CTA/49965/2003) 326 Projects. 


\section{REFERENCES}

Allen, C.E., Copley, J.T., Tyler, P., 2001. Lipid partitioning in the hydrothermal vent shrimp

Bandarra, N., Batista, I., Nunes, M., Empis, J., 2001. Seasonal variation in the chemical composition of horse-mackerel (Trachurus trachurus). European Food Research Technology, 212, $334535-539$.

Beninger, P.G., Stephan, G., 1985. Seasonal variations in the fatty acids of the triacylglycerols and phospholipids of two populations of adults clams (Tapes decussatus and T. philippinarum) reared in a common habitat. Comparative Biochemistry and Physiology B, 81B, 591-601.

Bergé, J-P., Barnathan, G., 2005. Fatty acids from lipids of marine organisms: molecular biodiversity, roles as biomarkers, biologically active compounds, and economical aspects. Advances in Biochemical Engineering / Biotechnology, 96, 49-125.

Bligh, E.G., Dyer, W.J., 1959. A rapid method for total lipid extraction and purification. Canadian 342 Journal of Biochemistry and Physiology, 3, 911-917.

343 Christie, W.W., 1989. The preparation of derivatives of fatty acids. In: Gas chromatography and 344 lipids. William W. Christie (Ed.). The Oily Press, Ayr, Scotland, p. 64-84.

345 Christie, W.L., 2007. The lipid library. Accessed 15 May. www.lipidlibrary.co.uk

346 Colaço, A., 2001. Trophic ecology of deep-sea hydrothermal vent fields from the Mid- Atlantic 347 Ridge. PhD dissertation, University of Lisbon, Lisbon, Portugal

348 Colaço, A., Dehairs, F., Desbruyeres, D., 2002. Nutritional relations of deep-sea hydrothermal 349 fields at the Mid-Atlantic Ridge: a stable isotope approach. Deep-Sea Research Part I, 49, 395-412. 

trophic links in chemosynthetic communities. Marine Ecology, 28, 15-24.

352

353

354

355

356

357

358

359

360

361

362

363

364

365

366

367

368

369

370

371

372

Colaço, A., Desbruyères, D., Comtet, T., Alayse, A.M., 1998. Ecology of the Menez-Gwen hydrothermal vent field. Cahiers de Biologie Marine, 39, 237-240.

Colaço, A., Martins, I., Laranjo, M., Pires, L., Leal, C., Prieto, C., Costa, V., Lopes, H., Rosa, D., Dando, P.R., Serrão-Santos, R., 2006. Annual spawning of the hydrothermal vent mussel, Bathymodiolus azoricus, under controlled aquarium conditions at atmospheric pressure. Journal of Experimental Marine Biology and Ecology, 333, 166-171.

Dalsgaard, J., St John, M., Kattner, G., Müller-Navarra, D., Hagen, W., 2003. Fatty acid trophic markers in the pelagic marine environment. Advances in Marine Biology, 46, 225-340.

Desbruyeres, D., Biscoito, M., Caprais, J.C., Colaco, A., Comtet, T., Crassous, P., Fouquet, Y., Khripounoff, A., Le Bris, N., Olu, K., Riso, R., Sarradin, P.M., Segonzac, M., Vangriesheim, A., 2001. Variations in Deep-Sea hydrothermal vent communities on the Mid-Atlantic Ridge near the Azores plateau. Deep-Sea Research Part I, 48, 1325-1346.

Dixon, D., Lowe, D., Miller, P., Villemin, G., Colaço, A., Serrão-Santos, R., Dixon, L., 2006. Evidence for seasonal reproduction in the Atlantic vent mussel Bathymodiolus azoricus, and an apparent link to the timing of photosynthetic primary production. Journal of Marine Biological Association of United Kingdom, 86, 1363-1371.

Dixon, D.R., Dando, P.R., Santos, R.S., Gwynn, J.P., 2001. Retrievable cages open up new era in deep-sea vent research. InterRidge News, 10, 21-23.

Duperron, S., Bergin, C., Zielinski, F., Blazejak, A., Pernthaler, A., Mckiness, Z.P., Dechaine, E., Cavanaugh, C.M., Dubilier, N., 2006. A dual symbiosis shared by two mussel species, Bathymodiolus azoricus and Bathymodiolus puteoserpentis (Bivalvia: Mytilidae), from 
373 hydrothermal vents along the northern Mid-Atlantic Ridge. Environmental Microbiology, 8, 1441-

3741447.

375 Fay, L., Richli, U., 1991. Location of double bonds in polyunsaturated fatty acids by gas

376 chromatography-mass spectrometry after 4,4-dymethyloxazoline derivatization. Journal of

377 Chromatography, 541, 89-98.

378 Fiala-Médioni, A., McKiness, Z.P., Dando, P., Boulegue, J., Mariotti, A., Alayse-Danet, A.M.,

379 Robinson, J.J., Cavanaugh, C.M., 2002. Ultrastructural, biochemical, and immunological

380 characterization of two populations of the mytilid mussel Bathymodiolus azoricus from the Mid-

381 Atlantic Ridge: evidence for a dual symbiosis. Marine Biology, 141 ,1035-1043.

382 Figueiredo, M., Martins, A., Castellanos, P., Mendonça, A., Macedo, L., Rodrigues, M., Lafon, V.,

383 Goulart, N., 2004. "HAZO: a software package for automated AVHRR and SeaWiFS aquisition

384 and processing", Arquivos do DOP, Série Relatórios Internos, 3/2004, 92 pp.

385 Fisher, C.R., Kennicutt II, M.C., Brooks, J.M., 1990. Stable Carbon isotopic evidence for carbon

386 limitation in hydrothermal vent vestimentiferans. Science, 247, 1094-1096.

387 Franz, B., "Implementation of SST Processing within the OBPG. OceanColor Documents" 388 (http://oceancolor.gsfc.nasa.gov/DOCS/modis_sst/) 2006.

389 Gardner, D., Riley, J.P., 1972. The component fatty acids of the lipids of some species of marine 390 and freshwater molluscs. Journal of Marine Biological Association of United Kingdom, 52, 827391832.

392 Gage, J.D., Tyler, P.A., 1991 Deep-Sea Biology: A natural history of organisms at the deep-sea 393 floor. Cambridge University Press 
Holland, D.L., 1978. Lipid reserves and energy metabolism in the larvae of benthic marine

395 invertebrates. In: Malins, D.C., Sargent, J.R. (Eds) Biochemical and Biophysical Perspectives in Marine Biology. Academic Press, London, U.K. 85-123pp.

Howell, K.L., Pond, D.W., Billet, D.S., Tyler, P.A., 2003. Feeding ecology of deep-sea seastars 255, 193-206.

Kharlamenko, V.I., Zhukova, N.V., Khotimchenko, S.V., Svetashev, V.I., Kamenev, G.M., 1995.

401 Fatty acids as markers of food sources in a shallow-water hydrothermal ecosystem (Kraternaya 402 Bight, Yankich Island, Kurile Islands). Marine Ecology Progress Series, 120, 231-241.

403

Kraffe, E., Soudant, P., Marty, Y., Kervarec, N., 2005. Docosahexaenoic acid- and 404 eicosapentaenoic acid-enriched cardiolipin in the manila clam Ruditapes philippinarum Lipids, 40, 405 619-625.

406 Kramer, J.K., Blackadar, C.B., Zhou, J., 2002. Evaluation of two GC columns (60 m Supelcowax 40710 and $100 \mathrm{~m} \mathrm{CP}$ Sil 88) for analysis of milkfat with emphasis on CLA, 18:1, 18:2 and 18:3 408 isomers, and short and long-chain fatty acids. Lipids, 37, 823-835 .

409 Laureillard, J., Mejanelle, L., Sibuet, M., 2004. Use of lipids to study the trophic ecology of deep410 sea xenophyophores. Marine Ecology Progress Series, 270, 129-140.

411 Legendre, P. Legendre, L., 1998. Numerical ecology. Elsevier Science, Amsterdam.

412 Le Pennec, M., Prieur, D., 1984. Observations sur la nutrition d'un Mytilidae d'un site 413 hydrothermal actif de la dorsal su Pacifique oriental. Comptes Rendus de L Academie des Sciences 414 Serie III, 298, 493-498. 
415 Morse, D.E., 1984. Biochemical and genetic engineering for improved production of abalones and 416 other valuable molluscs Aquaculture, 39, 263-282.

417 OceanColor Web. 2006. OceanColor level 1/2 browser.(Daily accessed) http:// 418 oceancolor.gsfc.nasa.gov/cgi/browse.pl.

419 O'Reilly, J.E., Maritorena, S., Siegel, D., O'Brien, M.C., Toole, D., Mitchell, B.G., Kahru, M., 420 Chavez, F.P., Strutton, P., Cota, G., Hooker, S.B., McClain, C.R., Carder, K.L., Muller-Karger, F., 421 Harding, L., Magnuson, A., Phinney, D., Moore, G.F., Aiken, J., Arrigo, K.R., Letelier, R., Culver, 422 M., 2000. Ocean color chlorophyll a algorithms for SeaWiFS, OC2, and OC4: Version 4. In: 423 Hooker, S.B., Firestone, E.R. (Eds). SeaWiFS Postlaunch Technical Report Series, Volume 11,

424 Park, Y., Albright, K.J., Cai, Z.Y., Pariza, M.W., 2001. Comparison of methylation procedures for 425 conjugated linoleic acid and artefact formation by commercial (trimethylsilyl) diazomethane. 426 Journal of Agricultural and Food Chemistry, 49, 1158-1164.

427 Pazos, A., Roma'n, G., Acosta, C., Sanchez, J., Abad, M., 1997. Lipid Classes and Fatty Acid 428 Composition in the Female Gonad of Pecten maximus in Relation to Reproductive Cycle and 429 Environmental Variables. Comparative Biochemistry and Physiology B,. 117, 393-402.

430 Phleger, C.F., Nelson, M.M., Mooney, B., Nichols, P.D., 1999. Lipids of abducted Antarctic 431 pteropods, Spongiobranchaea australis, and their hyperiid amphipod host. Comparative 432 Biochemistry and Physiology B,. 124, 295-307.

433 Pond, D., Gebruk, A., Southward, E.C., Southward, A.J., Fallick, A.E., Bell, M.V., Sargent, J.R., 434 2000. Unusual fatty acid composition of storage lipids in the bresilioid shrimp Rimicaris exoculata 435 couples the photic zone with MAR hydrothermal vent sites. Marine Ecology Progress Series, $436198,171-179$. 
Pond, D.W., Bell, M.V., Dixon, R.D., Fallick, A.E., Segonzac, M., Sargent, J.R., 1998. Stable-

carbon-isotope composition of fatty acids in hydrothermal vent mussels containing methanotrophic and thiotrophic bacterial endosymbionts. Applied and Environmental Microbiology, 64, 370-375.

Pruski, A.M., Dixon, D.R., 2003. Toxic vents and DNA damage: first evidence from a naturally contaminated deep-sea environment. Aquatic Toxicology, 64, 1-13.

Pruski, A.M., Dixon, D.R., 2007. Heat shock protein expression pattern (HSP70) in the hydrothermal vent mussel Bathymodiolus azoricus. Marine Environmental Research, 64, 209-224.

Raymont, J.E.G., 1983. Vertical migration of zooplankton In: Raymont J.E.G (Eds) Plankton and productivity in the oceans. V. 2, (pp. 489-524) Pergamon Press Ltd.

Sargent, J.R., 1995. Origins and functions of egg lipids: nutritional implications. In: Bromage NR, Roberts RJ (eds.), Broodstock Management and Egg and Larval Quality. Blackwell Science,

448 Oxford, p 353

Sargent, J.R., Bell, M.V., Bell, J.G., Henderson, R.J., Tocher, D.R., 1995. Origins and functions of n-3 polyunsaturated fatty acids in marine organisms. In: Cevc G, Paltauf F (eds.), Phospholipids: Characterization, Metabolism and Novel Biological Applications. AOCS, Champaign, Illinois, p 248

453 Sargent, J.R., Parkers, R.J., Mueller-Harvey, I., Henderson, R.J., 1987. Lipid biomarkers in marine 454 ecology. In: Sleigh, M.A. (Eds) Microbes in the Sea, E. Horwood Limited, 119-138 pp.

455 Sato, D., Ando, S., 2002. Distribution of novel nonmethhylene-interrupted fatty acids over neutral 456 and polar lipids of Ophiuroidea (Brittle star). Journal of Oleo Science, 51, 563-567.

457 SeaWiFS Postlaunch Calibration and Validation Analyses, Part 3. NASA, Goddard Space Flight 458 Center, Greenbelt, Maryland, 9-23pp. 
459 Soudant, P., Ryckeghem, K.V., Marty, Y., Moal, J., Samain, J.F., Sorgeloos, P., 1999. Comparison 460 of the lipid class and fatty acid composition between a reproductive cycle in nature and a standard 461 hatchery conditioning of the Pacific Oyster Crassostrea gigas. Comparative Biochemistry and 462 Physiology B, 123, 209-222.

463 Suhr, S.B., Pond, D.W., Gooday, A.J., Smith, C.R., 2003. Selective feeding by benthic 464 foraminifera on phytodetritus on the western Antarctic Peninsula shelf: evidence from fatty acid 465 biomarker analysis. Marine Ecology-Progress Series, 262, 153-162.

466 Swift, M.L., 1977. Phosphono-lipid content of the oyster, Crassostrea virginica, in three 467 physiological conditions. Lipids, 12, 449- 451.

468 White, D.C., Davis, W.M., Nickels, J.S., King, J.D., Bobbie, R.J., 1979. Determination of the 469 sedimentary microbial biomass by extractible lipid phosphate. Oecologia, 40, 51-62.

470 Zar, J.H., 1999. Biostatistical Analysis. Prentice-Hall, Inc. New Jersey. 
Fig. 1. MODIS/AQUA monthly median SST (in ${ }^{\circ} \mathrm{C}$ ) and Chl a (in $\mathrm{mg} \mathrm{m}^{-3}$ ) values for the Menez Gwen region from 2002-2008. Large dark grey squares represent autumn Chl a blooms, while the light grey circle represents the highest monthly median temperature value for the region.

Fig. 2. Principal component analyses with individuals as cases and fatty acids as descriptors. Winter stands for individuals collected in Winter; Spring for individuals collected in spring and Summer for individuals collected in Summer. N stands for nonpolar and $\mathrm{P}$ stands for polar fatty acids. Component 1 represents $71,73 \%$ of the variance, while the component 2 represents $16,85 \%$ of the variance. 


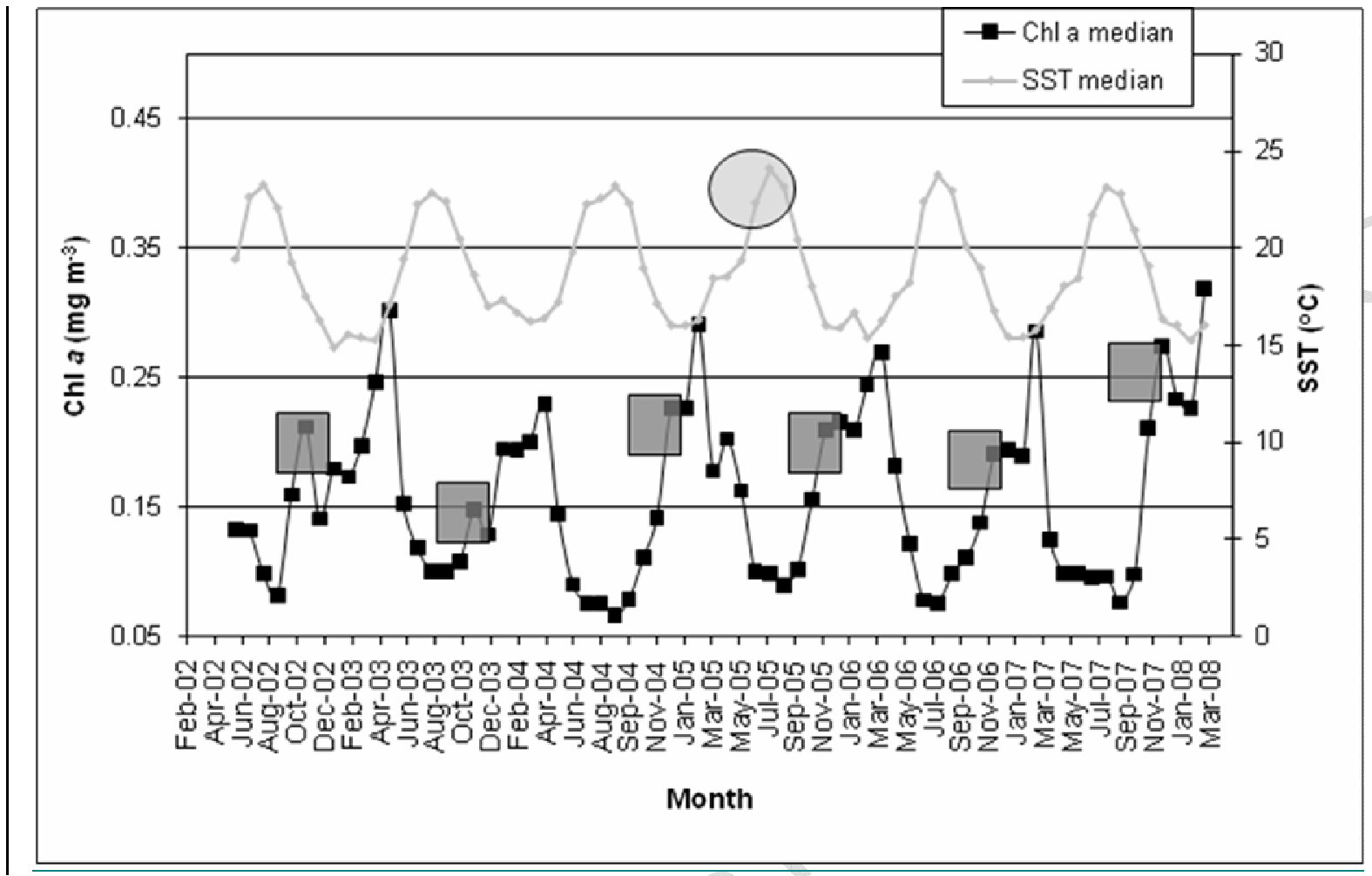




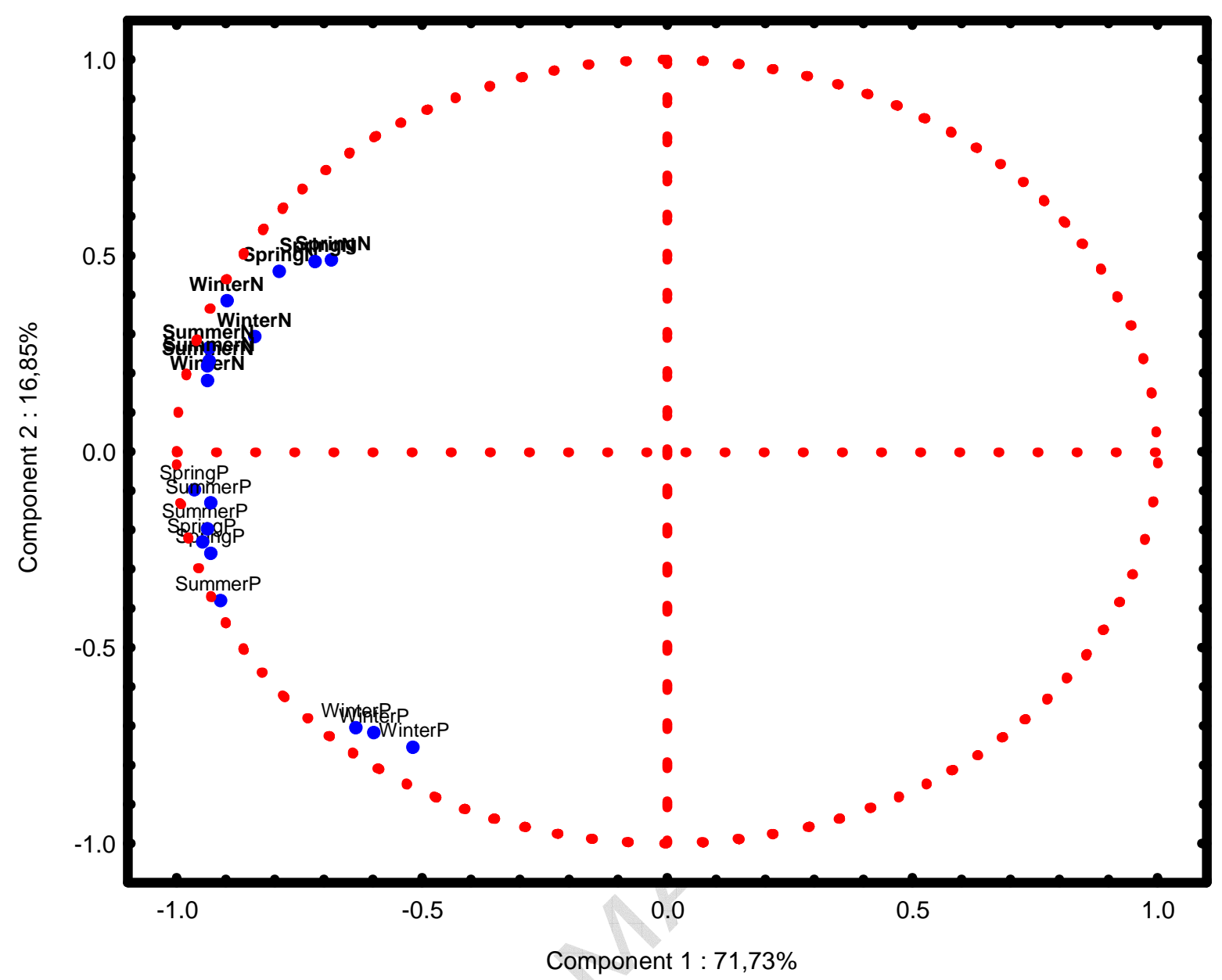

Fig.2 
Table 1. Lipid class composition by season of the mussel Bathymodiolus azoricus.

\begin{tabular}{|l|c|c|c|cc|c|c|}
\hline & Total lipids & Non-polar lipids (\%) & \multicolumn{5}{|c|}{ Polar lipids (\%) } \\
\cline { 4 - 7 } & & & PE & CL & PC & X & Total \% \\
\hline Winter $\mathrm{n}=2$ & $5.7 \pm 1.2$ & 91.3 & 6.8 & 0.3 & 1.2 & n.d. & 8.4 \\
Spring $\mathrm{n}=3$ & $3.3 \pm 0.7$ & 76.1 & 7.3 & n.d. & 14,0 & 1,9 & 23.2 \\
Summer $\mathrm{n}=3$ & $9.9 \pm 2.6$ & 76.4 & 14.5 & 3.3 & 4.5 & 1.0 & 23.3 \\
\hline
\end{tabular}

PE - Phosphatidylethanolamine; CL - Cardiolipine; PC - Phosphatidylcholine; X - Unknown Molecule n.d.-not detected 
Table 2. Fatty acid composition (mean percentage of total fatty acids \pm SD) of non-polar and polar lipids and total lipids extracted from mussels Bathymodiolus azoricus collected from the Menez Gwen vent field in different seasons. Total lipids are given as $\begin{array}{lllll}\mathrm{mg} & \mathrm{g}^{-1} \mathrm{dw} & \text { (mean } & \pm & \mathrm{SD} \text { ). }\end{array}$

\begin{tabular}{|c|c|c|c|c|c|c|}
\hline \multirow[b]{2}{*}{ Fatty acids } & \multicolumn{2}{|c|}{ Winter } & \multicolumn{2}{|c|}{ Spring } & \multicolumn{2}{|c|}{ Summer } \\
\hline & Non-polar lipids & Polar lipids & Non-polar lipids & Polar lipids & Non-polar lipids & Polar lipids \\
\hline 12:0 & $0.03 \pm 0.06$ & $0.1 \pm 0.08$ & $0.04 \pm 0.03$ & $0.18 \pm 0.05$ & nd & $0.05 \pm 0.02$ \\
\hline 13:0 & $0.08 \pm 0.09$ & $0.17 \pm 0.15$ & $0.03 \pm 0.01$ & $0.19 \pm 0.03$ & $0.03 \pm 0.01$ & $0.03 \pm 0.01$ \\
\hline 14:0 & $0.01 \pm 0.02$ & $0.94 \pm 0.86$ & $0.01 \pm 0.01$ & $1.92 \pm 0.60$ & $0.01 \pm 0.01$ & $2.22 \pm 0.52$ \\
\hline 14:0 isobr. & $0.05 \pm 0.02$ & $0.11 \pm 0.09$ & $0.03 \pm 0.00$ & $0.15 \pm 0.10$ & $0.04 \pm 0.02$ & $0.19 \pm 0.02$ \\
\hline 15:0 & $0.10 \pm 0.05$ & $0.2 \pm 0.18$ & $0.10 \pm 0.01$ & $0.31 \pm 0.06$ & $0.07 \pm 0.01$ & $0.23 \pm 0.01$ \\
\hline 15:1 & $0.06 \pm 0.05$ & $0.14 \pm 0.13$ & $0.06 \pm 0.04$ & $0.11 \pm 0.06$ & $0.03 \pm 0.01$ & $0.06 \pm 0.04$ \\
\hline 16:0 & $8.09 \pm 4.27$ & $6.05 \pm 5.20$ & $5.15 \pm 1.17$ & $10.03 \pm 0.85$ & $8.09 \pm 0.67$ & $9.90 \pm 0.315$ \\
\hline 16:1 19 & $0.52 \pm 0.89$ & $0.11 \pm 0.10$ & $0.63 \pm 0.59$ & $0.91 \pm 0.17$ & nd & $0.43 \pm 0.14$ \\
\hline $16: 1 \omega 7+\omega 6$ & $28.5 \pm 9.76$ & $5.30 \pm 5.22$ & $13.61 \pm 2.10$ & $19.38 \pm 1.57$ & $34.52 \pm 3.36$ & $27.24 \pm 1.28$ \\
\hline $16: 0$ iso & $0.17 \pm 0.12$ & $0.05 \pm 0.04$ & $0.14 \pm 0.10$ & $0.07 \pm 0.01$ & $0.05 \pm 0.02$ & $0.07 \pm 0.03$ \\
\hline 16:0 anteiso & $5.91 \pm 8.56$ & $0.73 \pm 0.63$ & $0.76 \pm 0.23$ & $0.90 \pm 0.19$ & $1.70 \pm 2.50$ & $0.20 \pm 0.06$ \\
\hline Phytanic & $0.01 \pm 0.01$ & $0.09 \pm 0.12$ & $0.01 \pm 0.01$ & $0.13 \pm 0.03$ & nd & $0.07 \pm 0.04$ \\
\hline $17: 0$ & $0.04 \pm 0.01$ & $0.14 \pm 0.19$ & $0.04 \pm 0.01$ & $0.50 \pm 0.11$ & $0.03 \pm 0.01$ & $0.29 \pm 0.04$ \\
\hline $17: 1 \omega 6+\omega 7$ & $0.11 \pm 0.06$ & $0.06 \pm 0.09$ & $0.18 \pm 0.01$ & $0.22 \pm 0.17$ & $0.17 \pm 0.02$ & $0.14 \pm 0.01$ \\
\hline $16: 4 \omega 3$ & $0.20 \pm 0.09$ & $1.32 \pm 1.07$ & $0.41 \pm 0.13$ & $0.93 \pm 0.14$ & $0.12 \pm 0.05$ & $1.52 \pm 0.04$ \\
\hline 18:0 & $0.03 \pm 0.00$ & $1.8 \pm 1.59$ & $0.03 \pm 0.03$ & $3.14 \pm 0.61$ & $0.04 \pm 0.07$ & $2.23 \pm 0.24$ \\
\hline 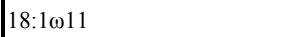 & $0.02 \pm 0.02$ & $0.08 \pm 0.07$ & $0.01 \pm 0.02$ & $0.87 \pm 0.18$ & nd & $1.10 \pm 0.25$ \\
\hline $18: 1 \omega 9-\mathrm{c} * \omega 13$ & $1.25 \pm 0.39$ & $4.92 \pm 1.36$ & $1.46 \pm 0.34$ & $3.80 \pm 1.41$ & $1.73 \pm 0.10$ & $2.55 \pm 0.46$ \\
\hline $18: 1 \omega 7+\omega 6+\omega 8$ & $0.43 \pm 0.23$ & $1.74 \pm 0.57$ & $0.45 \pm 0.10$ & $4.24 \pm 1.15$ & $0.67 \pm 0.10$ & $3.49 \pm 0.27$ \\
\hline 18:3 NMI & $0.54 \pm 0.22$ & $1.36 \pm 0.28$ & $0.47 \pm 0.07$ & $5.56 \pm 1.64$ & $0.87 \pm 0.17$ & $8.07 \pm 0.73$ \\
\hline 18:3 NMI & $0.07 \pm 0.03$ & $0.05 \pm 0.05$ & $0.06 \pm 0.02$ & $0.12 \pm 0.05$ & $4.06 \pm 0.21$ & $0.03 \pm 0.01$ \\
\hline $18: 2 \omega 6$ & $0.60 \pm 0.11$ & $0.36 \pm 0.10$ & $0.04 \pm 0.06$ & $0.80 \pm 0.39$ & $1.34 \pm 0.09$ & $0.78 \pm 0.08$ \\
\hline $18: 4 \omega 3$ & $0.16 \pm 0.13$ & $1.66 \pm 0.88$ & $0.45 \pm 0.33$ & $2.31 \pm 0.46$ & $0.24 \pm 0.01$ & $3.00 \pm 0.47$ \\
\hline $20: 0$ & $0.16 \pm 0.05$ & $0.07 \pm 0.13$ & $0.53 \pm 0.44$ & $0.19 \pm 0.09$ & $0.15 \pm 0.03$ & $0.91 \pm 1.48$ \\
\hline $20: 1 \omega 8+\omega 14$ & $0.23 \pm 0.06$ & $0.63 \pm 0.10$ & nd & $3.67 \pm 0.92$ & $0.07 \pm 0.06$ & $3.79 \pm 0.49$ \\
\hline $20: 1 \omega 7+\omega 6$ & $6.73 \pm 2.39$ & $0.78 \pm 0.03$ & $5.78 \pm 0.97$ & $4.19 \pm 2.18$ & $9.82 \pm 0.51$ & $5.33 \pm 0.89$ \\
\hline $20: 2 \omega 6$ & $0.15 \pm 0.08$ & $0.19 \pm 0.10$ & $0.12 \pm 0.05$ & $0.87 \pm 0.21$ & $0.23 \pm 0.05$ & $1.14 \pm 0.13$ \\
\hline $20: 3 \omega 6$ & $0.02 \pm 0.03$ & $50.58 \pm 20.29$ & $0.01 \pm 0.01$ & $11.02 \pm 2.60$ & nd & $10.87 \pm 1.38$ \\
\hline $20: 2 \omega(9,15)+\omega(7,15)+\omega(6,15)$ & $3.43 \pm 2.93$ & nd & $2.63 \pm 0.62$ & $0.06 \pm 0.07$ & $0.92 \pm 0.04$ & $0.07 \pm 0.09$ \\
\hline $20: 3 \omega 3$ & $0.08 \pm 0.06$ & $0.16 \pm 0.15$ & $0.01 \pm 0.01$ & $0.27 \pm 0.04$ & $0.09 \pm 0.05$ & $0.17 \pm 0.04$ \\
\hline $20: 3 \omega 6$ & $0.03 \pm 0.02$ & $0.1 \pm 0.09$ & $0.09 \pm 0.03$ & $0.11 \pm 0.01$ & $0.07 \pm 0.02$ & $0.06 \pm 0.03$ \\
\hline $20: 4 \omega 6$ & $0.02 \pm 0.02$ & $2.22 \pm 1.02$ & $0.74 \pm 0.62$ & $3.12 \pm 2.16$ & $0.04 \pm 0.02$ & $0.59 \pm 0.47$ \\
\hline 22:0 & $0.07 \pm 0.12$ & nd & nd & $0.26 \pm 0.07$ & $0.01 \pm 0.01$ & $0.04 \pm 0.05$ \\
\hline 22:1œ11 & nd & $0.11 \pm 0.12$ & nd & $0.78 \pm 0.06$ & nd & $0.66 \pm 0.26$ \\
\hline $22: 1 \omega 9$ & $0.71 \pm 0.67$ & $0.38 \pm 0.11$ & $0.21 \pm 0.03$ & $0.47 \pm 0.08$ & $0.32 \pm 0.18$ & $0.26 \pm 0.31$ \\
\hline $22: 1 \omega 7$ & $2.43 \pm 0.92$ & $1.82 \pm 0.87$ & $7.98 \pm 0.10$ & $3.82 \pm 1.02$ & $0.96 \pm 0.17$ & $2.81 \pm 0.53$ \\
\hline 22:3 NMI & $1.78 \pm 0.92$ & $0.06 \pm 0.09$ & $2.01 \pm 0.30$ & $0.60 \pm 0.24$ & $1.96 \pm 0.07$ & $0.34 \pm 0.03$ \\
\hline $22: 2 \omega(9,15)$ & $6.36 \pm 3.54$ & $0.04 \pm 0.06$ & $20.67 \pm 2.14$ & $0.39 \pm 0.12$ & $3.97 \pm 1.09$ & $0.37 \pm 0.07$ \\
\hline $22: 5 \omega 6$ & $0.12 \pm 0.06$ & $0.09 \pm 0.13$ & $0.23 \pm 0.18$ & $0.17 \pm 0.16$ & nd & $0.03 \pm 0.04$ \\
\hline $22: 5 \omega 3$ & $0.14 \pm 0.18$ & $0.01 \pm 0.02$ & $0.19 \pm 0.03$ & $0.07 \pm 0.04$ & $0.09 \pm 0.05$ & $0.10 \pm 0.09$ \\
\hline $22: 6 \omega 3$ & $0.20 \pm 0.08$ & $4.64 \pm 2.49$ & $1.23 \pm 0.60$ & $1.09 \pm 0.96$ & $0.27 \pm 0.23$ & $0.54 \pm 0.30$ \\
\hline$\Sigma$ saturated & $8.61 \pm 4.67$ & $9.47 \pm 8.27$ & $5.93 \pm 1.70$ & $16.72 \pm 2.47$ & $8.43 \pm 0.15$ & $15.90 \pm 2.68$ \\
\hline$\Sigma$ MUFA & $40.99 \pm 15.44$ & $15.96 \pm 8.77$ & $30.37 \pm 4.3$ & $42.46 \pm 8.97$ & $48.34 \pm 4.51$ & $47.86 \pm 4.93$ \\
\hline S PUFA & $13.9 \pm 8.5$ & $59.29 \pm 17.39$ & $29.81 \pm 3.97$ & $27.49 \pm 9.08$ & $14.27 \pm 2.15$ & $27.68 \pm 4.00$ \\
\hline$\Sigma$ branched & $6.15 \pm 8.72$ & $0.98 \pm 0.89$ & $0.97 \pm 0.34$ & $2.01 \pm 0.45$ & $1.81 \pm 2.56$ & $0.48 \pm 0.10$ \\
\hline$\Sigma$ NMI & $12.21 \pm 7.66$ & $1.61 \pm 0.57$ & $25.93 \pm 3.18$ & $12.78 \pm 2.13$ & $11.85 \pm 1.6$ & $8.94 \pm 0.96$ \\
\hline Not identified or $<0,01$ & $30,36 \pm 37,32$ & $10,64 \pm 44,85$ & $33,4 \pm 11,55$ & $12,08 \pm 21,06$ & $27,22 \pm 10,02$ & $8,03 \pm 11,76$ \\
\hline total lipids ( $\mathrm{mg} \cdot \mathrm{g}^{-1} \mathrm{dwt}$ ) & \multicolumn{2}{|c|}{$46.3 \pm 22.1$} & \multicolumn{2}{|c|}{$14.0 \pm 1.6$} & \multicolumn{2}{|c|}{$189.7 \pm 53.8$} \\
\hline
\end{tabular}

n.d.- not detected 